\title{
Erratum to: Access to primary care in adults in a provincial correctional facility in Ontario
}

Samantha Green ${ }^{\text {* }}$, Jessica Foran ${ }^{2}$ and Fiona G. Kouyoumdjian ${ }^{3}$

\section{Erratum to: BMC Res Notes (2016) 9:131 DOI 10.1186/s13104-016-1935-4}

Unfortunately, the original version of this article [1] was missing funding information within the Acknowledgements section.

The research for this article was funded by the Hamilton Community Foundation.

\section{Author details}

${ }^{1}$ Department of Family and Community Medicine, St. Michael's Hospital, 30 Bond Street, Toronto, ON M5B 1W8, Canada. ${ }^{2}$ Department of Political Science, McMaster University, Hamilton, ON, Canada. ${ }^{3}$ Centre for Research on Inner City Health, St. Michael's Hospital, Toronto, ON, Canada.

The online version of the original article can be found under doi:10.1186/s13104-016-1935-4.

Received: 14 September 2016 Accepted: 3 October 2016 Published online: 11 October 2016

\section{Reference}

1. Green S, Foran J, Kouyoumdjian FG. Access to primary care in adults in a provincial correctional facility in Ontario. BMC Res Notes. 2016;9:131. doi:10.1186/s13104-016-1935-4.

\footnotetext{
${ }^{*}$ Correspondence: greensa@smh.ca

${ }^{1}$ Department of Family and Community Medicine, St. Michael's Hospital,

30 Bond Street, Toronto, ON M5B 1W8, Canada

Full list of author information is available at the end of the article
} provided you give appropriate credit to the original author(s) and the source, provide a link to the Creative Commons license, and indicate if changes were made. The Creative Commons Public Domain Dedication waiver (http://creativecommons.org/ publicdomain/zero/1.0/) applies to the data made available in this article, unless otherwise stated. 